\title{
Diversity in root growth responses to moisture deficit in young faba bean (Vicia faba L.) plants
}

\author{
Kiflemariam Yehuala Belachew ${ }^{\text {Corresp., }}{ }^{2}$, Kerstin A Nagel ${ }^{2}$, Fabio Fiorani ${ }^{2}$, Frederick L Stoddard ${ }^{1}$ \\ ${ }^{1}$ Department of Agricultural Sciences, Viikki Plant Science Centre, University of Helsinki, Helsinki, South Finland, Finland \\ 2 IBG-2: Plant Sciences, Forschungszentrum Jülich GmbH, Jülich, Germany \\ Corresponding Author: Kiflemariam Yehuala Belachew \\ Email address: kiflemariam.belachew@helsinki.fi
}

Background. Soil moisture deficiency causes yield reduction and instability in faba bean (Vicia faba L.) production. The extent of sensitivity to drought stress varies across accessions originating from diverse moisture regimes of the world. Hence, we conducted successive greenhouse experiments in pots and rhizotrons to explore diversity in root responses to soil water deficit.

Methods. A set of 89 accessions from wet and dry growing regions of the world was defined according to the Focused Identification of Germplasm Strategy and screened in a perlite-sand medium under well watered conditions in a greenhouse experiment. Stomatal conductance, canopy temperature, chlorophyll concentration, and root and shoot dry weights were recorded during the fifth week of growth. Eight accessions representing the range of responses were selected for further investigation. Starting 5 days after germination, they were subjected to a root phenotyping experiment using the automated phenotyping platform GROWSCREEN-Rhizo. The rhizotrons were filled with peat-soil under well watered and water limited conditions. Root architectural traits were recorded 5, 12, and 19 days after the treatment (DAT) began.

Results. In the germplasm survey, accessions from dry regions showed significantly higher values of chlorophyll concentration, shoot and root dry weights than those from wet regions. Root and shoot dry weight as well as seed weight, and chlorophyll concentration were positively correlated with each other. Accession DS70622 combined higher values of root and shoot dry weight than the rest. The experiment in GROWSCREEN-Rhizo showed large differences in root response to water deficit. The accession by treatment interactions in taproot and second order lateral root lengths were significant at 12 and 19 DAT, and the taproot length was reduced up to $57 \%$ by drought. The longest and deepest root systems under both treatment conditions were recorded by DS70622 and DS11320, and total root length of DS70622 was three times longer than that of WS99501, the shortest rooted accession. The maximum horizontal distribution of a root system and root surface coverage were positively correlated with taproot and total root lengths and root system depth. DS70622 and WS99501 combined maximum and minimum values of these traits, respectively. Thus, roots of DS70622 and DS11320, from dry regions, showed droughtavoidance characteristics whereas those of WS99501 and Mèlodie/2, from wet regions, showed the opposite.

Discussion. The combination of the germplasm survey and use of GROWSCREEN-Rhizo allowed exploring of adaptive traits and detection of root phenotypic markers for potential drought avoidance. The greater root system depth and root surface coverage, exemplified by DS70622 and DS11320, can now be tested as new sources of drought tolerance. 
1 Diversity in root growth responses to moisture deficit in young faba bean (Vicia faba L.)

2 plants

3 Kiflemariam Y. Belachew ${ }^{1}$, Kerstin A. Nagel ${ }^{2}$, Fabio Fiorani ${ }^{2}$, Frederick L. Stoddard ${ }^{1}$

$4{ }^{1}$ Department of Agricultural Sciences, Viikki Plant Science Centre, University of Helsinki, PO

5 Box 27 (Latokartanonkaari 5), FIN 00014, Helsinki, Finland

$6 \quad{ }^{2}$ Forschungszentrum Jülich GmbH, IBG-2: Plant Sciences, 52425 Jülich, Germany

7 Corresponding Author: Kiflemariam Belachew

8 Email: kiflemariam.belachew@helsinki.fi 
10

11

12

13

14

15

\section{Abstract}

Background. Soil moisture deficiency causes yield reduction and instability in faba bean (Vicia faba L.) production. The extent of sensitivity to drought stress varies across accessions originating from diverse moisture regimes of the world. Hence, we conducted successive greenhouse experiments in pots and rhizotrons to explore diversity in root responses to soil water deficit.

Methods. A set of 89 accessions from wet and dry growing regions of the world was defined according to the Focused Identification of Germplasm Strategy and screened in a perlite-sand medium under well watered conditions in a greenhouse experiment. Stomatal conductance, canopy temperature, chlorophyll concentration, and root and shoot dry weights were recorded during the fifth week of growth. Eight accessions representing the range of responses were selected for further investigation. Starting 5 days after germination, they were subjected to a root phenotyping experiment using the automated phenotyping platform GROWSCREEN-Rhizo. The rhizotrons were filled with peat-soil under well watered and water limited conditions. Root architectural traits were recorded 5, 12, and 19 days after the treatment (DAT) began.

Results. In the germplasm survey, accessions from dry regions showed significantly higher values of chlorophyll concentration, shoot and root dry weights than those from wet regions. Root and shoot dry weight as well as seed weight, and chlorophyll concentration were positively correlated with each other. Accession DS70622 combined higher values of root and shoot dry weight than the rest. The experiment in GROWSCREEN-Rhizo showed large differences in root response to water deficit. The accession by treatment interactions in taproot and second order lateral root lengths were significant at 12 and 19 DAT, and the taproot length was reduced up to $57 \%$ by drought. The longest and deepest root systems under both treatment conditions were 
recorded by DS70622 and DS11320, and total root length of DS70622 was three times longer than that of WS99501, the shortest rooted accession. The maximum horizontal distribution of a root system and root surface coverage were positively correlated with taproot and total root lengths and root system depth. DS70622 and WS99501 combined maximum and minimum values of these traits, respectively. Thus, roots of DS70622 and DS11320, from dry regions, showed drought-avoidance characteristics whereas those of WS99501 and Mèlodie/2, from wet regions, showed the opposite.

Discussion. The combination of the germplasm survey and use of GROWSCREEN-Rhizo allowed exploring of adaptive traits and detection of root phenotypic markers for potential drought avoidance. The greater root system depth and root surface coverage, exemplified by DS70622 and DS11320, can now be tested as new sources of drought tolerance.

\section{INTRODUCTION}

Faba bean (Vicia faba L.) is an agronomically important crop for sustainable cropping systems (de Visser, Schreuder \& Stoddard, 2014) and has value for both food and feed (Crépon et al., 2010). Drought poses a great challenge to the sustainable production of the crop (Khan et al., 2010). Most faba bean genotypes are sensitive to soil moisture loss and heat stress (Loss,

Siddique \& Martin, 1996), showing leaf wilting symptoms even at moderate soil water potential (McDonald \& Paulsen, 1997). Yield losses and instability are the main problems of this crop in drought-affected areas (Khan et al., 2010). Nevertheless, faba bean shows drought adaptation potential in the field (Reid, 1990) and diversity exists in abiotic stress tolerance (Khazaei et al., 2013; Belachew \& Stoddard, 2017). For example, line ILB938 has demonstrated drought tolerance in different experiments in controlled conditions (Link et al., 1999; Khan et al., 2007). Khazaei et al. (2013) studied the leaf morphophysiological traits of two sets of 201 faba bean 
56 accessions collected from dry and wet regions of the world, chosen according to the Focused

57 Identification of Germplasm Strategy (FIGS), which is based on the concept that traits are the

58 outward expressions of the environment in which the genotypes evolved. The "dry set" included

59 accessions collected from sites where the annual rainfall was between 300 and $550 \mathrm{~mm}$, whereas

60 the "wet set" accessions were collected from sites receiving an annual rainfall of more than 800

$61 \mathrm{~mm}$ (Khazaei et al., 2013). The results indicated the potential of FIGS in the search for target

62 traits for drought stress adaptation, but its focus on leaf traits left root traits open for later study.

63 High-throughput screening and phenotyping of plants grown in pots allows controlled and

64 uniform moisture stress, which is difficult to achieve under field conditions (Tuberosa, 2012).

65 Screening of faba bean in well watered conditions provided initial information about leaf traits

66 related to drought adaptation (Khazaei et al., 2013). Leaf chlorophyll content is a key trait

67 determining the source capacity in affecting cumulative photosynthesis (Tuberosa, 2012) and in

68 peanut (Arachis hypogaea L.), it is positively correlated with dry root biomass and used to

69 discriminate accessions for drought stress (Songsri et al., 2009). Stomatal conductance and

canopy temperature depression (CTD) are two methods to screen cool-season legumes for

71 drought stress (Stoddard et al., 2006). Large stomatal response, which is the expression of

sensitivity to soil moisture deficiency, is regarded as useful for long-term drought (Munns et al.,

73 2010) and considered as a consistent indicator of growth rate response to stress. CTD, the

74 difference in temperature between the canopy surface and the surrounding air, incorporates the

75 effects of multiple biochemical and morphophysiological features acting at the root, stomata and

76 the plant canopy (Tuberosa, 2012). Accessions exhibiting cooler canopy temperature under

77 drought stress avoid excessive dehydration through the use of more of the available moisture in

78 the soil. Hence, CTD indicates plant water status in monitoring plant responses to water stresses 
79 (Tarek et al., 2014) and it is reported as the most responsive trait in faba bean accessions (Khan

80 et al., 2007; Khazaei, 2014).

81 Together with shoot traits, identifying root phenotypic markers will help to understand the

82 mechanisms by which they affect tolerance to drought. Root studies in legumes are relatively

83 few and much less is known about roots than about shoots. When plants were grown in tall

84 cylinders containing 1:1 Vertisol:Sand mixture $(\mathrm{w} / \mathrm{w})$, trait diversity for drought tolerance in

85 chickpea (Cicer arietinum L.) was readily detected, including deeper rooting and greater biomass

86 proportion in roots (Kashiwagi et al., 2006). Shovelomics and automated image phenotyping

87 methods revealed genotypic variation in cowpea (Vigna unguiculata (L.) Walp.) root

88 architecture, such as number of lateral roots and volume of soil enclosed by roots (Burridge et

89 al., 2017). In a controlled environment, GROWSCREEN-Rhizo, a novel automated phenotyping

90 robot, enables relatively high-throughput and non-invasive root phenotyping through

91 characterization of root geometry (Nagel et al., 2012; Gioia et al., 2015; Avramova et al., 2016).

92 With this tool, images are captured in real time and the functional and structural parts of the crop

93 are quantified using image analysis software (Nagel et al., 2009; Rascher et al., 2011; Nagel et

94 al., 2012).

95 For these reasons, we set out to investigate variation in root morphology of faba bean. The first

96 hypothesis, tested with a germplasm survey, was that dry-zone germplasm would have more

97 prolific root systems than wet-zone germplasm. The second hypothesis, tested with the

98 phenotyping robot, was that dry-zone germplasm would maintain its root system growth better in

99 drought than wet-zone germplasm would.

100 MATERIAL AND METHODS 
101

102

103

104

105

106

107

108

109

110

111

112

113

114

115

116

117

118

119

120

121

122

123

\section{Germplasm Survey}

The germplasm survey was conducted at the University of Helsinki's Viikki Campus greenhouse facility in a randomized complete block design (RCBD) with 4 replications. The four blocks were sown at 7-day intervals (owing to space limitation) and allowed to grow for 34 days and each block contained one pot of each accession. Throughout the experiment, the photoperiod was set at $14 \mathrm{~h}$ light and $10 \mathrm{~h}$ dark, and the temperature maintained at $22{ }^{\circ} \mathrm{C}$ during the day and $16{ }^{\circ} \mathrm{C}$ in the night.

The original set of 201 wet-adapted and 201 dry-adapted accessions (Khazaei et al., 2013) was reduced to 88 based on differences in canopy temperature depression measured in the glasshouse (Khazaei et al., 2013), country of origin and availability of seeds. Ten other accessions (7 from Ethiopia and 3 from Europe) were selected from the previous screening experiment for acid-soil and aluminium toxicity tolerance (Belachew \& Stoddard, 2017). ILB938/2 and Mélodie/2 were included as they have been well studied previously (Link et al., 1999; Khan et al., 2007; Khazaei et al., 2013). Poor germination of 11 accessions reduced this set of 100 to 89,44 of which were from the previous dry set, 38 from the wet set and 7 from Ethiopian highlands that conform to the criteria of the wet set (Table 1). Since seed quantities were limited, seed size was evaluated as one-tenth of 10-seed weight rather than hundred- or thousand-seed weight.

The experiment was designed to maximize expression of potential root mass by providing plentiful moisture and nutrients. The pots were $3 \mathrm{~L}$ in capacity, $20 \mathrm{~cm}$ deep and $15 \mathrm{~cm}$ diameter with 4 drainage holes of $2 \mathrm{~cm}$ diameter. The bottom of each pot was covered with a thin membrane sheet and then the pots were filled with $0.2 \mathrm{~L}$ of sand at the bottom, 2.6 L of perlite, and $0.2 \mathrm{~L}$ of sand on the top. Two seeds per pot were sown and after 5 days, the weaker seedling was removed, leaving the stronger seedling to grow. Nutrient solution was applied at $200 \mathrm{~mL}$ 
124 automatically every other day from sowing to harvesting for 34 days to keep the medium at field

125 capacity. Pests (thrips) were controlled biologically with parasitic wasps. The nutrient solution

126 was $1 \mathrm{~g} / \mathrm{L}$ of Superex Peat (Kekkilä Oy, Vantaa, Finland) supplemented with $2 \mathrm{mmol} / \mathrm{L} \mathrm{CaCl}_{2}$, as

127 previously described (Belachew \& Stoddard, 2017).

128 At BBCH stage 39 (Meier, 2001), when there were approximately 9 visibly extended internodes,

129 30-34 days after sowing (DAS), the following measurements were taken. Stomatal conductance

130 was measured using a Leaf Porometer (Decagon Devices, Inc, Pullman, WA, U.S.A.) once per

131 plant. Leaf surface temperature was measured using a FLUKE Model 574 Precision Infrared

132 Thermometer (Fluke Corporation, Everett, WA, U.S.A.), chlorophyll concentration was

133 measured as leaf SPAD values from two leaves per plant and the average of the two was

134 recorded using SPAD-502 (Minolta Camera Co, Ltd, Japan). Measurements were taken between

135 11:00 and 13:00 local time. Plants were harvested at 34 DAS. Shoots were removed above the

136 collar region and roots were carefully removed from the perlite. Both parts were dried in a drying

137 oven at $70{ }^{\circ} \mathrm{C}$ for $48 \mathrm{~h}$. Root and shoot dry weight were measured to the nearest $0.01 \mathrm{~g}$ and root

138 to shoot dry weight ratio was calculated by dividing the root weight by the corresponding shoot

139 weight. Root mass fraction was calculated as root dry mass divided by total plant dry biomass.

\section{Root Phenotyping Experiment}

141 The experiment was conducted at Jülich Plant Phenotyping Center (JPPC) (www.jppc.de),

142 Forschungszentrum Jülich GmbH, Germany from 23 January to 20 February 2017.

143 Eight accessions were chosen (Table 1) from the germplasm survey according to their

144 performance in stomatal conductance, canopy temperature, chlorophyll concentration, root and

145 shoot dry weights and root mass fraction values. Accessions showing high values of stomatal

146 conductance and leaf surface temperature were considered as potentially drought susceptible, 
147 whereas those showing high chlorophyll concentration, root dry weight, root to shoot dry weight

148 ratio, and root mass fraction, along with low values of stomatal conductance and leaf surface

149 temperature were considered as potentially drought tolerant.

150 The experiment was conducted in the automated root and shoot phenotyping platform

151 GROWSCREEN-Rhizo using rhizotrons with a size of $90 \times 70$ × $5 \mathrm{~cm}$ (Nagel et al., 2012). The

152 growth medium used was GRAB-ERDE, a dark peat-based substrate (Plantaflor Humus

153 Verkaufs-GmbH, Germany). A total of $2400 \mathrm{~L}$ peat was first machine broken and then passed

154 through a $0.8 \mathrm{~cm}$ sieve. The initial moisture content of the peat-soil was $66.3 \%$ measured using

155 Electronic Moisture Analyzer (version 1.1, 03/2013, KERN and Sohn GmbH, Germany). Of this,

$1561600 \mathrm{~L}$ was air dried to $40 \%$ moisture content, when it had a water potential of $0.006 \mathrm{MPa}$

157 according to the water retention curve analysis conducted by the Institute of Plant Nutrition and

158 Soil Science, University of Kiel, Germany.

159 Nutrient content and other physical and chemical properties of the growth medium were

160 analyzed by LUFA NRW Laboratory, Germany. Dry matter content was 35\%, wet bulk density

$161450 \mathrm{~g} / \mathrm{L}$, dry bulk density $158 \mathrm{~g} / \mathrm{L}, \mathrm{pH} 5.8$, EC $733 \mu \mathrm{S} / \mathrm{cm}, \mathrm{KCl}$ in $\mathrm{H}_{2} \mathrm{O} 1.76 \mathrm{~g} / \mathrm{L}, \mathrm{KCl}$ in $\mathrm{CaSO}_{4}$

$1620.45 \mathrm{~g} / \mathrm{L}$, total nitrogen $27 \mathrm{mg} / \mathrm{L}$ in $\mathrm{CaCl}_{2} / \mathrm{DPTA}$-Extract (CAT, where DPTA is

163 diethylenetriamine-pentaacetic acid), $\mathrm{NH}_{4}^{+}-\mathrm{N} 4 \mathrm{mg} / \mathrm{L}$ in CAT, $\mathrm{NO}_{3}^{-}-\mathrm{N} 23 \mathrm{mg} / \mathrm{L}$ in CAT, $\mathrm{P}_{2} \mathrm{O}_{5} 22$

$164 \mathrm{mg} / \mathrm{L}$ in CAT, $\mathrm{K}_{2} \mathrm{O} 178 \mathrm{mg} / \mathrm{L}$ in CAT, $\mathrm{Mg} 125 \mathrm{mg} / \mathrm{L}$ in CAT, and $\mathrm{Mn} 11 \mathrm{mg} / \mathrm{L}$ in CAT.

165 Water-limited treatment boxes were filled with air dried peat-soil, whereas well watered

166 treatment boxes were filled without drying. Each rhizotron contained approximately $21 \mathrm{~L}$ of

167 growth medium. Filling was done in 3 steps of $7 \mathrm{~L}$ peat-soil each followed by regular pressing,

168 to make the compaction of the medium as uniform as possible among boxes. The boxes were

169 then fixed in the robotic system in the greenhouse and tilted at $43^{\circ}$ from vertical. 
170

171

172

173

174

175

176

177

178

179

180

181

182

183

184

185

186

187

188

189

190

191

\section{Research design}

The experiment was arranged in a split-plot design, with 4 replicate blocks, 2 treatments (well watered and water limited) as the main plots and 8 accessions as subplots.

\section{Planting and treatment management}

The experiment was conducted for 28 days, from seed soaking to plant harvesting, during the vegetative stage of plant growth. Seeds of uniform size were selected from all 8 accessions, washed three times, surface sterilized with $1 \% \mathrm{NaClO}$ (sodium hypochlorite) (w/v) for 5 min and rinsed 3 times with running tap water. The seeds were soaked in tap water for $24 \mathrm{~h}$, transferred to three layers of moist filter paper in $14 \mathrm{~cm}$ diameter Petri dishes (14 seeds/dish) as described in Belachew and Stoddard (2017), and incubated for $96 \mathrm{~h}$ at $22^{\circ} \mathrm{C}$ in the dark. The seedlings showing uniform root growth were selected and transferred into the rhizotrons. Initially, for establishment, each seedling in well watered treatment received $200 \mathrm{ml}$ water in the automatic irrigation system and those in water limited treatment received $50 \mathrm{ml}$ of water to their roots manually. Following this, the well watered plants were given $100 \mathrm{ml}$ of water every $12 \mathrm{~h}$ until the end of the treatment period. In the water-limited treatment, plants received the second $50 \mathrm{ml}$ of water 4 days after transplanting and thereafter received no more water. The average peat-soil temperature was $22.6^{\circ} \mathrm{C}$, air humidity $58 \%$ and air temperature $20.9^{\circ} \mathrm{C}$. The photoperiod was 15 $\mathrm{h}$ light and $9 \mathrm{~h}$ dark.

\section{Data collected}

Root images were automatically taken every day except on Saturday and Sunday from 30 January to 20 February 2017. Images taken 5 days after treatment (DAT), 12 DAT, and 19 DAT were analyzed using the PaintRHIZO software package and dimensions were converted to SI 
192 units using 55.53 pixel $=1 \mathrm{~cm}$. The following root distribution and individual root traits were 193 computed (Nagel et al., 2009 \& 2012):

194

195

196

197

198

200

201

202

203

204

205

206

207

208

209

210

211

212 $213 \& 2012)$

- taproot length $(\mathrm{cm})$;

- $\quad$ first and second order lateral roots length $(\mathrm{cm})$;

- $\quad$ total root length $(\mathrm{cm})$;

- root system depth $(\mathrm{cm})$, which represents the maximum vertical distribution of the root system;

- root system width $(\mathrm{cm})$, which represents maximum horizontal distribution of the root system; and

- convex hull area $\left(\mathrm{cm}^{2}\right)$, which measures the surface area along the transparent plate of the rhizotrons covered by a root system.

To evaluate how much of the whole root system was visible at the transparent plate of the rhizotrons, we measured total root length destructively, using accession DS70622 as a test-case because it had the largest root system in both irrigation treatments. The roots were carefully removed from the potting medium 19 days after the treatment, washed, and preserved in ethanol solution until analysis. One week later, each root system was thoroughly washed, cut into manageable lengths and spread in water on the WinRhizo scanner.

\section{Data analysis}

Root images obtained with GROWSCREEN-Rhizo and manual root scanner EPSON A3 Transparency Unit (Model EU-88, Japan) were analyzed using PaintRHIZO and WinRHIZO, respectively, following the methods developed by Mühlich et al. (2008) and Nagel et al. (2009 
214 Quantitative data from the survey and the phenotyping experiment were subjected to analysis of

215 variance using SPSS version 22.0 (IBM Inc., Chicago, IL, USA). Frequency distributions of the

216 survey data showed that most measures gave acceptable fits to the normal distribution. Stomatal

217 conductance and root-to-shoot dry weight ratio both showed excess kurtosis values above 4, and

218 their skewness values were 0.9 and 1.5 , respectively, owing to a single outlying accession in

219 each case. Treatment means were separated by Duncan's Alpha (5\%). The difference between

220 the group means of the dry-adapted and wet-adapted sets in the germplasm survey was tested

221 using an independent-samples t-test. In the phenotyping experiment, the two-way ANOVA

222 tested the main effect of treatment, the main effect of accession, and the treatment by accession

223 interaction effect on each sampling date $(5,12$, and 19 DAT) separately. A t-test was used to

224 compare the difference in root visibility of DS70622 between watering treatments.

\section{RESULTS}

\section{Germplasm Survey}

227 There were significant differences between accessions in stomatal conductance, chlorophyll concentration, root and shoot dry weight and root mass fraction values $(\mathrm{P}<0.001)$, root to shoot dry weight ratio $(\mathrm{P}<0.01)$ and leaf surface temperature $(\mathrm{P}<0.05)$. Stomatal conductance ranged 6fold, shoot dry weight 12-fold, root dry weight 7-fold, root mass fraction 2-fold, seed size 18fold and leaf surface temperature by $3.1^{\circ} \mathrm{C}$ (Table 2 ). Accessions originating from dry growing regions of the world showed significantly higher chlorophyll concentration $(\mathrm{P}<0.001)$, shoot $(\mathrm{P}<0.01)$ and root $(\mathrm{P}<0.001)$ dry weights than those from wet regions (Table 2 and Table $\mathrm{S} 1)$.

234 Chlorophyll concentration showed a weak but significant negative correlation with stomatal 
236 shoot dry weight were positively correlated with each other (Fig. 1) and with seed weight (Table

237 3). Root mass fraction was negatively correlated with seed weight.

238 The five accessions with the greatest root and shoot weights were from the dry set and the five

239 with the lowest were from the wet set (Fig. 1). The accessions with the two greatest total dry

240 weights were DS70622 (5.1 g) and DS74573 (4.8 g) (Fig. 1). Accession DS11320 was an outlier

241 with the highest value of stomatal conductance, along with a one of the highest values of root dry

242 weight. Accession WS114476 was an outlier with the highest value of root-to-shoot dry weight

243 ratio, but this was combined with very low total dry weight production. Eight accessions (Table

244 4) were chosen for the root phenotyping experiment.

\section{Root Phenotyping}

246 The water-limited treatment was sufficiently strong to reduce the lengths of all three classes of

247 root (taproot, lateral and second order lateral roots) at all three time points $(5,12$ and 19 days

248 after treatment started (DAT)) below the values found in the well watered treatment (Fig. 2 and

249 Table S2). The main effect of accession on all three root lengths was also significant at all time

250 points. The treatment $\mathrm{x}$ accession effect was significant for taproot and second order lateral root

251 lengths at 12 and 19 DAT, but not for lateral root lengths, in which the standard error was large.

252 Lateral roots made the largest contribution to total root length at 19 DAT (Fig. 2), 76\% in well

253 watered and $79 \%$ in water limited, a non-significant difference.

254 At 19 DAT, accession DS70622 had the longest lateral roots in both treatments, the longest

255 second order lateral roots in the well watered treatment, the greatest total root length in both

256 treatments, and the smallest difference in taproot and lateral root growth between treatments

257 (Fig. 2). DS11320 had the longest tap root, the second-longest laterals and the second-longest 
258 total root length in the well watered treatment. EH06006-6 had the second-longest taproots in the

259 well watered treatment. Mélodie/2 had the shortest taproot, lateral and second order lateral roots

260 in the well watered treatment, whereas in the water-limited treatment, DS74573 had the shortest

261 tap root, and WS99501 had the shortest laterals, second order laterals and total root length (Fig.

262 2).

263 In three of the eight accessions, second order lateral roots were not visible at 5 DAT (Table S2).

264 In the water-limited condition, only two of the accessions showed second order lateral roots at 12

265 DAT, but at 19 DAT, all of the test materials had these roots.

266 At 19 DAT, genotypic mean total root length and genotypic mean root system depth were

267 positively correlated $(\mathrm{r}=0.86, \mathrm{n}=8, \mathrm{P}<0.01)$, as were taproot length and total root length $(\mathrm{r}=0.82$, $268 \mathrm{n}=8, \mathrm{P}<0.05)$.

269 At the end of the treatment period, the genotypic mean total root length of DS70622 was 3 times 270 longer than those of Mélodie/2 and WS99501. Accessions DS11320 and DS70622 showed the 271 two deepest root systems consistently at all 3 time points and WS99501 had the shallowest root 272 system (Table 5 and Table S3).

273 On average, the total root length and root system depth recorded under well watered condition 274 was twice that in the water-limited condition. Droughted roots continued to grow throughout the 275 experiment, but more slowly than in well watered conditions, such that the total root length of 276 the droughted treatment was $50 \%, 41 \%$ and $27 \%$ of non-droughted at 5,12 , and 19 DAT, 277 respectively (Fig. 2 \& Table S3). Similarly, root system depth was reduced by 40\%, 46\%, and $27850 \%$, respectively, at these three time points (Table 5 and Table S3). 
279 Comparison of total root length records obtained from PaintRHIZO and WinRHIZO image

280 analysis software of accession DS70622 indicated that roots in rhizotrons were $32.4 \%$ visible.

281 The difference in visibility between the two treatments, $25.5 \%$ in the well watered condition and

$28239.3 \%$ in the water-limited condition, was not statistically significant by a t-test.

283 Root system width differed between treatments, being $46 \mathrm{~cm}$ in the well watered condition and

$28428 \mathrm{~cm}$ in the water-limited treatment, but there was no significant difference between accessions.

285 Convex hull area showed large differences between treatments and between accessions (Fig. 3),

286 but the interaction was not significant (Table 5). Treatment differences in convex hull area

287 increased across the 3 time points (Table 5 and Table S3). Plants grown in the well watered

288 condition showed about 3 times more convex hull area than plants grown in the water-limited

289 condition. Maximum convex hull area was shown in accession DS70622, closely followed by

290 EH06006-6 and DS11320, while WS99501 and Mélodie/2 had the two minimum values (Table

291 5). Root system width and convex hull area (genotypic means) were positively correlated

$292(\mathrm{r}=0.97, \mathrm{n}=8, \mathrm{P}<0.01)$, and both traits were positively correlated with taproot length, total root

293 length, and root system depth ( $\mathrm{r}=0.82$ to $0.89, \mathrm{n}=8, \mathrm{P}<0.01, \mathrm{P}<0.05)$.

294 DISCUSSION

295 The germplasm survey showed that there was wide variation in morphological root traits of faba

296 bean and that they were correlated with shoot traits, but that there were important outliers from

297 that correlation. In the root phenotyping experiment, the water deficit was sufficiently harsh that

298 it affected the length and width of all root systems, but there were large differences among

299 accessions. Accession DS70622 had a larger root system than the benchmark drought-tolerant

300 accession, ILB938/2, so it may be a potential source of genes for drought avoidance by improved

301 access to soil water. These results are discussed below. 
302 Accessions from dry regions of the world showed higher chlorophyll concentration, and root and 303 shoot dry weight than those from wet regions in the survey. Increased chlorophyll concentration 304 and SPAD value were observed due to drought in peanut genotypes and chlorophyll stability was 305 reported to be an indicator of drought tolerance in that species (Arunyanark et al., 2008). High

306 SPAD values and high root dry weight were positively correlated in lentil (Lens culinaris Medik)

307 in response to drought (Kumar et al., 2012) and the decrease in chlorophyll content in drought

308 tolerant genotypes of barley (Hordeum vulgare L.) was much less than in drought susceptible 309 ones (Li et al., 2006). The correlation between growth of different plant parts is expected, and it 310 leads to relatively consistent root:shoot ratio or root mass fraction (RMF). The outliers from the correlation are interesting as sources of potential breeding traits. In the present survey, root mass

312 fraction ranged relatively widely, from 0.24 to 0.50 , at 34 DAS. In a set of 211 chickpea 313 accessions, RMF ranged from 0.38 to 0.53 at 35 DAS (Kashiwagi et al., 2005). The generally 314 higher value of chickpea RMF may relate to its acknowledged greater drought tolerance. The 315 outliers above regression line (Fig. 1) in the current set of faba bean were mostly in accessions 316 from the "wet set", indicating that there may be useful sources of drought tolerance among this material. Our recalculations of RMF values from literature show higher values in each paper from drought-tolerant lines than from drought-susceptible ones: 0.57 to 0.66 in 133 recombinant inbred lines of lentil (Idrissi et al., 2015), 0.44 to 0.47 in 40 genotypes of lentil (Sarker, Erskine \& Singh, 2005), and 0.20 to 0.25 in cowpea (Vigna unguiculata (L.) Walp.) genotypes (Matsui \&

321 Singh, 2003).

322 The substantial reduction in root length early in the phenotyping experiment emphasizes the

323 importance of establishing faba beans with adequate moisture, particularly in agricultural regions 324 subject to water deficit (Loss, Siddique \& Martin, 1996). The reduction in root length was highly 
325 variable among accessions, being as high as 77\% in DS74573 and as low as 30\% in DS70622

326 (Fig. 2) at 19 DAT. This variation was shown to be significant in the accession by treatment

327 interaction beginning from 12 DAT. The taproot of DS70622 in the water-limited condition was

328 nearly 6x and 3x longer than those of WS99501 and Mèlodie/2, respectively. Similarly, drought-

329 tolerant cultivars of common bean showed deeper roots than the sensitive ones (Sponchiado et

330 al., 1989). Increased fine root length density and fine root dry weight was reported in white lupin

331 (Lupinus albus L.) in response to water deficit (Rodrigus, Pacheco \& Chaves, 1995). Lentil

332 genotypes with longer roots and greater root dry weight were reported to tolerate terminal

333 drought better than those with shorter roots and lower root weight (Kumar et al., 2012). Deep-

334 rooted pulses can benefit from stored water in times of drought more readily than shallow-rooted

335 ones (French \& White, 2005).

336 Root phenotyping technology provides new opportunities for assessing the effect of stress on

337 different classes of root. Drought limited the length of laterals and second order lateral roots

338 beginning from the onset of the treatment period. In sorghum (Sorghum bicolor Moench), the

339 production of seminal root laterals was hindered by drought at the onset of the treatment and

340 nodal roots produced few laterals only after some time (Pardales \& Kono, 1990). Chickpea

341 produced longer laterals when sown with sufficient moisture than when droughted

342 (Krishnamurthy, Johansen \& Ito, 1994). Mélodie/2 and WS99501 showed the greatest

343 detrimental effect of drought already at 5 DAT and continued in that way for the rest of the

344 experiment (Fig. 2 \& Table S2). Even DS70622, the most prolifically rooting accession, did not

345 show second order lateral roots in the water-limited condition until at least 12 DAT. Though the

346 formation was first noted late, at 19 DAT, this accession was found to have the second longest

347 second order lateral roots next to DS74573. 
348 There were positive correlations between root area coverage (root system width and convex hull

349 area) and root depth (tap root and total root lengths, and root system depth) measurements,

350 indicating that faba beans expand their root system in depth and breadth in a more or less

351 balanced way. However, though convex hull area showed large differences between treatments

352 and among accessions, there was no accession by treatment interaction suggesting a strong

353 genetic effect. Drought-tolerant chickpea genotypes showed adaptive root distribution, with a

354 higher root length density at deeper soil layers during a severe drought year (Kashiwagi et al.,

355 2006), whereas roots of this species remained near the surface in moist conditions (Benjamin \&

356 Nielsen, 2006). This plasticity is especially important for the crop to avoid both terminal drought

357 (Kashiwagi et al., 2006; Gaur, Krishnamurthy \& Kashiwagi, 2008) as well as transient drought.

358 Peanut genotypes with a large root system showed high water use efficiency under drought

359 condition (Songsri et al., 2009). Prolific and deep root systems have been shown in drought-

360 avoiding accessions of chickpea (Kashiwagi et al., 2005), cowpea (Matsui \& Singh, 2003), field

361 pea (Pisum sativum L.) and soybean (Glycine max (L.) Merr.) (Benjamin \& Nielsen, 2006).

362 Hence, accessions with a larger root system probably avoid drought through increased access to

363 water in the soil by increased tap root length as well as overall root system depth and width.

364 In the germplasm survey, the benchmark accessions Mélodie/2 and ILB938/2 showed low

365 stomatal conductance, high chlorophyll concentration, and low shoot and root dry weight as

366 compared to the rest. This was in agreement with the findings of Khazaei et al. (2013) in which

367 Mélodie/2 and ILB 938/2 were reported to express efficient use of water and water use

368 efficiency, respectively. In the root phenotyping experiment, however, the two accessions

369 performed well below other accessions such as DS70622 and DS11320. This contradiction might

370 be due to the initiation of the treatment at a much earlier stage of growth, which is in agreement 
371 with the finding that the root distribution of peanut genotypes at 37 and 67 days after sowing did

372 not adequately predict the effects of drought, and best prediction being obtained at 97 days after

373 sowing (Songsri et al., 2008). There are many ways in which plants respond to water deficit

374 (Pereira \& Chaves, 1993). Those from dry areas may show tolerance by increased root system

375 depth and cavitation resistance (Hacke, Sperry \& Pittermann, 2000), root growth at the expense

376 of above-ground parts (Husain et al., 1990; Reid, 1990), osmotic regulation and solute buildup,

377 and expression of aquaporins (Lian et al., 2004; Galmés et al., 2007). Crop plants that tolerate

378 drought through the biosynthesis of abscisic acid (ABA) may also show reduced water use and

379 low biomass production because of low leaf growth, low stomatal conductance (Galmés et al.,

380 2007) and hence low photosynthesis even in wet growing conditions (Tardieu, 2003). ILB938/2

381 follows this model. Other plant internal changes can regulate the opening of stomata as well

382 (Galmés et al., 2007).

\section{CONCLUSIONS}

384 The GROWSCREEN-Rhizo phenotyping platform allowed detection of useful differences in

385 root responses to water deficit. In both the survey and the rhizotron experiments, the shoot and

386 root traits varied widely among accessions, and these traits were positively correlated among

387 each other. In both cases, higher values of morpho-physiological shoot and root measurements

388 were recorded from accessions originating from the drier growing regions of the world,

389 confirming the significance of FIGS to identify drought-adaptive traits.

390 The growth of the root system of faba bean in depth and width followed a balanced pattern, a

391 strategy of wider and deeper soil exploration for water. Accession DS70622 produced the

392 greatest root mass in the survey and phenotyping treatments, and maintained its root mass and 393 convex hull area under stress. In the water-limited treatment, accession DS11320 produced 
394 considerably less root mass than DS70622, but combined this with a high convex hull area, and 395 in the survey it had by far the highest stomatal conductance, suggesting that it was efficient at 396 finding water. Thus, these two accessions can be new sources of root traits for future breeding of 397 drought tolerant cultivars. 


\section{ACKNOWLEDGEMENT}

400

401

402

403

404

405

406

407

408

409

410

411

412

413

414

415

416

417

418

419

420

421

422

423

424

425

426

427

428

We acknowledge Sebastien Carpentier, Astrid Junker, and Andreas Voloudakis for facilitating the STSM application with COST Action FA 1306. We thank Markku Tykkyläinen, Jouko Närhi and Sanna Peltola for their greenhouse assistance in the screening experiment in Helsinki, Anna Galinski, Henning Lenz, Bernd Kastenholz, Beate Uhlig, Carmen Müller, Jonas Lentz, and AnnKatrin Kleinert for their assistance in the laboratory and greenhouse activities in Jülich, and Hendrik K. Poorter for his valuable comments during the conduct of the research. We also thank Jülich Plant Phenotyping Center (JPPC), IBG-2: Plant Sciences for hosting the root phenotyping research in their facility.

\section{REFERENCES}

Arunyanark A, Jogloy S, Akkasaeng C, Vorasoot N, Kesmala T, Rao RCN, Wright GC, Patanothai A. 2008. Chlorophyll stability is an indicator of drought tolerance in peanut. Journal of Agronomy and Crop Science 194:113-125.

Avramova V, Nagel KA, AbdElgawad H, Bustos D, DuPlessis M, Fiorani F, Beemster GTS. 2016. Screening for drought tolerance of maize hybrids by multi-scale analysis of root and shoot traits at the seedling stage. Journal of Experimental Botany 67:2453-2466.

Belachew KY, Stoddard FL. 2017. Screening of faba bean (Vicia faba L.) accessions to acidity and aluminium stresses. PeerJ, 5:e2963; DOI 10.77171/peerj.2963.

Benjamin JG, Nielsen DC. 2006. Water deficit effects on root distribution of soybean, field pea and chickpea. Field Crops Research 97:248-253.

Burridge JD, Schneider HM, Huynh B-L, Roberts PA, Bucksch A, Lynch JP. 2017. Genomewide association mapping and agronomic impact of cowpea root architecture. Theoretical and Applied Genetics 130:419-431.

Crépon K, Marget P, Peyronnet C, Carrouée B, Arese P, Duc G. 2010. Nutritional value of faba bean (Vicia faba L.) seeds for food and feed. Field Crops Research 115:329-339.

de Visser CLM, Schreuder R, Stoddard F. 2014. The EU's dependency on soybean import for the animal feed industry and potential for EU produced alternatives. OCL, 21:D407. DOI: $10.1051 / \mathrm{ocl} / 2014021$.

French B, White P. 2005. Soil and environmental factors affecting pulse adaptation in Western Australia. Australia Journal of Agricultural Research 50:375-387. 
429

430

431

432

433

434

435

436

437

438

439

440

441

442

443

444

445

446

447

448

449

450

451

452

453

454

455

456

457

458

459

460

461

462

463

464

465

Galmés J, Pou A, Alsina MM, Tomàs M, Medrano H, Flexas J. 2007. Aquaporin expression in response to different water stress intensities and recovery in Richter-110 (Vitis sp.): relationship with ecophysiological status. Planta 226:671-681.

Gaur PM, Krishnamurthy L, Kashiwagi J. 2008. Improving drought-avoidance traits in chickpea (Cicer arietinum L.) - Current status of research at ICRISAT. Plant Production Science 11:3-11.

Gioia T, Nagel KA, Beleggia R, Fragasso M, Ficco DBM, Pieruschka R, De Vita P, Fiorani F, Papa R. 2015. The impact of domestication on the phenotypic architecture of durum wheat under contrasting nitrogen fertilization. Journal of Experimental Botany 66:5519-5530.

Hacke UG, Sperry JS, Pittermann J. 2000. Drought experience and cavitation resistance in six shrubs from the Great Basin, Utah. Basic and Applied Ecology 1:31-41.

Husain HM, Reid JB, Othman H, Gallagher JN. 1990. Growth and water use of faba beans (Vicia $f a b a)$ in a sub-humid climate I. Root and shoot adaptations to drought stress. Field Crops Research 23:1-17.

Idrissi O, Houasli C, Udupa SM, Keyser ED, Van Damme P, De Riek J. 2015. Genetic variability for root and shoot traits in a lentil (Lens culinaris Medik) recombinant inbred line population and their association with drought tolerance. Euphytica 204:693-709.

Kashiwagi J, Krishnamurthy L, Crouch JH, Serraj R. 2006. Variablilty of root length density and its contributions to seed yield in chickpea (Cicer arietinum L.) under terminal drought stress. Field Crops Research 95:171-181.

Kashiwagi J, Krishnamurthy L, Upadhyaya HD, Krishna H, Chandra S, Vadez V, Serraj R. 2005. Genetic variability of drought avoidance root traits in the mini-core germplasm collection of chickpea (Cicer arietinum L.). Euphytica 146:213-222.

Khan HR, Paull JG, Siddique KHM, Stoddard FL. 2010. Faba bean breeding for droughtaffected environments: Aphysiological and agronomic perspective. Field Crops Research 115:279-286.

Khan HrR, Link W, Hocking TJ, Stoddard FL. 2007. Evaluation of physiological traits for improving drought tolerance in faba bean (Vicia faba L.). Plant Soil 292:205-217.

Khazaei H, Street K, Bari A, Mackay M, Stoddard FL. 2013. The FIGS (Focused Identification of Germplasm Strategy) approach identifies traits related to drought adaptation in Vicia faba genetic resources. PLoS ONE 8: e63107.

Khazaei H. 2014. Leaf traits associated with drought adaptation in faba bean (Vicia faba L.). D. Phil. Thesis, University of Helsinki, Finland.

Krishnamurthy L, Johansen C, Ito O. 1994. Genotypic variation in root system development and its implications for drought resistance in chickpea. In: Ito O, Johansen C, Adu-Gyamfi JJ, Katayama K, Kumar Rao JVDK, Rego TJ, eds. Roots and Nitrogen in Cropping Systems of the Semi-arid Tropics. Proceedings of the International Workshop: Dynamics of the semi-arid tropics, ICRISAT, Patancheru, Andhra Pradesh, India 21-25 November 1994. Pp. 235-250. 
466 Kumar J, Basu PS, Srivastava E, Chaturuedi SK, Nadarajan N, Kumar S. 2012. Phenotyping of 467 traits imparting drought tolerance in lentil. Crop and Pasture Science 63:547-554.

468 Li R-h, Guo P-g, Baum M, Grando S, Ceccarelli S. 2006. Evaluation of chlorophyll content and

469

470

471

472

473

474

475

476

477

478

479

480

481

482

483

484

485

486

487

488

489

490

491

492

493

494

495

496

497

498

499 fluorescence parameters as indicators of drought tolerance in barley. 2006. Agricultural Sciences in China 5:751-757.

Lian H-L, Yu X, Ye Q, Ding X-S, Kitagawa Y, Kwak S-S, Su W-A, Tang Z-C. 2004. The role of aquaporin RWC3 in drought avoidance in rice. Plant and Cell Physiology 45:481-489.

Link W, Abdelmula AA, von Kittlitz E, Bruns S, Riemer H, Stelling D. 1999. Genotypic

variation for drought tolerance in Vicia faba. Plant Breeding 118:477-483.

Loss SP, Siddique KHM, Martin LD. 1996. Adaptation of faba bean (Vicia faba L.) to dryland Mediterranean-type environments II. Phenology, canopy development, radiation absorption and biomass partitioning. Field Crops Research 52:29-41.

Matsui T, Singh BB. 2003. Root characteristics in cowpea related to drought tolerance at the seedling stage. Experimental Agriculture 39:29-38.

McDonald GK, Paulsen GM. 1997. High temperature effects on photosynthesis and water relations of grain legumes. Plant Soil 196:47-58.

Meier U. 2001. Growth stages of mono- and dicotyledonous plants: BBCH Mongoraph (2nd ed.). Federal Biological Research Centre for Agriculture and Forestry, Berlin.

Mühlich M, Truhn D, Nagel KA, Walter A, Scharr H, Aach T. 2008. Measuring plant root growth. Pattern recognition: $30^{\text {th }}$ DAG Symposium Munich, Germany. Lecture Notes in Computer Science 5096:497-506.

Munns R, James RA, Sirault XRR, Furbank RT, Jones HG. 2010. New phenotyping methods for screening wheat and barley for beneficial responses to water deficit. Journal of Experimental Botany, 61:3499-3507.

Nagel KA, Kastenholz B, Jahnke S, van Dusschoten D, Aach T, Mühlich M, Truhn D, Scharr H, Terjung S, Walter A, Schurr U. 2009. Temperature responses of roots: impact on growth, root system architecture and implications for phenotyping. Functional Plant Biology 36:947-959.

Nagel KA, Putz A, Gilmer F, Heinz K, Fischbach A, Pfeifer J, Faget M, Blossfeld S, Ernst M, Dimaki C, Kastenholz B, Kleinert A-K, Galinski A, Scharr H, Fiorani F, Schurr U. 2012. GROWSCREEN-Rhizo is a novel phenotyping robot enabling simultaneous measurements of root and shoot growth for plants grown in soil-filled rhizotrons. Functional Plant Biology 39:891-904.

Pardales JJR, Kono Y. 1990. Development of sorghum root system under increasing drought stress. Japan Journal of Crop Science 59:752-761. 
500 Pereira JS, Chaves MM. 1993. Plant water deficits in Mediterranean ecosystem. In: Smith JAC, 501 Griffiths H, eds. Plant responses to Water Deficits - from Cell to Community. Oxford: BIOS

502 Scientific Publishers Ltd, 237-251.

503 Rascher U, Blossfeld S, Fiorani F, Jahnke S, Jansen M, Kuhn AJ, Matsubara S, Märtin LLA, 504 Merchant A, Metzner R, Müller-Linow M, Nagel KA, Pieruschka R, Pinto F, Schreiber CM, 505 Temperton VM, Thorpe MR, van Dusschoten D, van Volkenburgh E, Windt CW, Schurr U. 506 2011. Non-invasive approaches for phenotyping of enhanced performance traits in bean.

507 Functional Plant Biology 38:968-983.

508 Reid JB. 1990. Growth and water use of faba beans (Vicia faba) in a sub-humid climate II.

509 Simulation analysis of crop responses to drought. Field Crops Research 23:19-38.

510 Rodrigus ML, Pacheco CMA, Chaves MM. 1995. Soil-plant water relations, root distribution 511 and biomass partitioning in Lupinus albus L. under drought conditions (abstract). Journal of 512 Experimental Botany 46:947-956.

513 Sarker A, Erskine W, Singh M. 2005. Variation in shoot and root characteristics and their 514 association with drought tolerance in lentil landraces. Genetic Resources and Crop Evolution $515 \quad 52: 89-97$.

516 Songsri P, Jogloy S, Holbrook CC, Kesmala T, Vorasoot N, Akkasaeng C, Patanothai A. 2009.

517 Association of root, specific leaf area and SPAD chlorophyll meter reading to water use 518 efficiency of peanut under different available soil water. Agricultural Water Management 519 96:790-798

520 Songsri P, Jogloy S, Vorasoot N, Akkasaeng C, Patanothai A, Holbrook CC. 2008. Root 521 distribution of drought-resistant peanut genotypes in response to drought. Journal of Agronomy 522 and Crop Science 194:92-103.

523 Sponchiado BN, White JW, Cstillo JA, Jones PG. 1989. Root growths of four common bean 524 cultivars in relation to drought tolerance in environments with contrasting soil types.

525 Experimental Agriculture 25:249-257.

526 Stoddard FL, Balko C, Erskine W, Khan HR, Link W, Sarker A. 2006. Screening techniques and 527 sources of resistance to abiotic stresses in cool-season food legumes. Euphytica 147:167-186.

528 Tardieu F. 2003. Virtual plants: modelling as a tool for the genomics of tolerance to water 529 deficit. Trends in Plant Science 8:9-14.

530 Tarek YB, Salah El-H, Mohamed SHY, Mohamed A ElGE, Salah AA ElGO. 2014. Application 531 of infrared thermal imagery for monitoring salt tolerant of wheat genotypes. The Journal of 532 American Science 10:227-234.

533 Tuberosa R. 2012. Phenotyping for drought tolerance of crops in the genomics era. Frontiers in 534 Physiology 3:347. DOI:10.3389/fphys.2012.00347. 


\section{Table $\mathbf{1}$ (on next page)}

List of experimental materials by country of origin and source.

GU is University of Göttingen; HARC is Holeta Agricultural Research Center, Ethiopia; ICARDA is International Center for Agricultural Research in the Dry Areas; INRA is French National Institute for Agricultural Research; Prefixes DS and WS indicate material originally allocated to the dry set and wet set (Khazaei et al., 2013). Accessions with asterisk were used in the subsequent root phenotyping experiment. 


\begin{tabular}{|c|c|c|c|c|c|c|c|c|c|c|c|}
\hline S.N & $\begin{array}{l}\text { Accession } \\
\mathrm{s}\end{array}$ & $\begin{array}{l}\text { Country of } \\
\text { origin }\end{array}$ & Source & $\begin{array}{l}\text { S.N } \\
.\end{array}$ & Accessions & $\begin{array}{l}\text { Country of } \\
\text { origin }\end{array}$ & Source & S.N & $\begin{array}{l}\text { Accession } \\
\mathrm{s}\end{array}$ & $\begin{array}{l}\text { Country of } \\
\text { origin }\end{array}$ & Source \\
\hline 1 & Aurora & Sweden & Svalöf Weibull & 31 & DS137675 & Tajikistan & ICARDA & 61 & $\begin{array}{l}\text { WS11513 } \\
4\end{array}$ & Nepal & $\begin{array}{l}\text { ICARD } \\
\text { A }\end{array}$ \\
\hline 2 & Babylon & $\begin{array}{l}\text { Netherland } \\
\mathrm{s}\end{array}$ & $\begin{array}{l}\text { Nickerson } \\
\text { Limagrain }\end{array}$ & 32 & DS13918 & Sudan & ICARDA & 62 & $\begin{array}{l}\text { WS11517 } \\
7\end{array}$ & Nepal & $\begin{array}{l}\text { ICARD } \\
\text { A }\end{array}$ \\
\hline 3 & DOSHA & Ethiopia & HARC & 33 & DS70622* & Syria & ICARDA & 63 & $\begin{array}{l}\text { WS11518 } \\
2\end{array}$ & Nepal & $\begin{array}{l}\text { ICARD } \\
\text { A }\end{array}$ \\
\hline 4 & DS11202* & Jordan & ICARDA & 34 & DS72271 & Morocco & ICARDA & 64 & $\begin{array}{l}\text { WS11518 } \\
6\end{array}$ & Nepal & $\begin{array}{l}\text { ICARD } \\
\mathrm{A}\end{array}$ \\
\hline 5 & DS11207 & Syria & ICARDA & 35 & DS72309 & Syria & ICARDA & 65 & $\begin{array}{l}\text { WS11535 } \\
2\end{array}$ & Nepal & $\begin{array}{l}\text { ICARD } \\
\mathrm{A}\end{array}$ \\
\hline 6 & DS112096 & Morocco & ICARDA & 36 & DS72310 & Syria & ICARDA & 66 & $\begin{array}{l}\text { WS11543 } \\
0\end{array}$ & Nepal & $\begin{array}{l}\text { ICARD } \\
\text { A }\end{array}$ \\
\hline 7 & DS11210 & Syria & ICARDA & 37 & DS72366 & Syria & ICARDA & 67 & WS11688 & $\begin{array}{l}\text { Afghanista } \\
n\end{array}$ & $\begin{array}{l}\text { ICARD } \\
\text { A }\end{array}$ \\
\hline 8 & DS11236 & Iraq & ICARDA & 38 & DS72387 & Syria & ICARDA & 68 & $\begin{array}{l}\text { WS11783 } \\
0\end{array}$ & China & $\begin{array}{l}\text { ICARD } \\
\text { A }\end{array}$ \\
\hline 9 & DS11281 & Afghanistan & ICARDA & 39 & DS72396 & Syria & ICARDA & 69 & $\begin{array}{l}\text { WS11784 } \\
1\end{array}$ & China & $\begin{array}{l}\text { ICARD } \\
\text { A }\end{array}$ \\
\hline 10 & DS11286 & Iran & ICARDA & 40 & DS72455 & Syria & ICARDA & 70 & $\begin{array}{l}\text { WS11784 } \\
9\end{array}$ & China & $\begin{array}{l}\text { ICARD } \\
\text { A }\end{array}$ \\
\hline 11 & DS11294 & Spain & ICARDA & 41 & DS72493 & Syria & ICARDA & 71 & $\begin{array}{l}\text { WS11785 } \\
3\end{array}$ & China & $\begin{array}{l}\text { ICARD } \\
\text { A }\end{array}$ \\
\hline 12 & DS11317 & Macedonia & ICARDA & 42 & DS72523 & Syria & ICARDA & 72 & $\begin{array}{l}\text { WS11785 } \\
5\end{array}$ & China & $\begin{array}{l}\text { ICARD } \\
\mathrm{A}\end{array}$ \\
\hline 13 & DS11320* & Macedonia & ICARDA & 43 & DS74370 & Oman & ICARDA & 73 & $\begin{array}{l}\text { WS11785 } \\
7\end{array}$ & China & $\begin{array}{l}\text { ICARD } \\
\text { A }\end{array}$ \\
\hline 14 & DS11437 & Turkey & ICARDA & 44 & DS74554 & Algeria & ICARDA & 74 & $\begin{array}{l}\text { WS11786 } \\
4\end{array}$ & China & $\begin{array}{l}\text { ICARD } \\
\text { A }\end{array}$ \\
\hline 15 & DS11480 & Lebanon & ICARDA & 45 & DS74573* & Russia & ICARDA & 75 & $\begin{array}{l}\text { WS11786 } \\
8\end{array}$ & China & $\begin{array}{l}\text { ICARD } \\
\text { A }\end{array}$ \\
\hline 16 & DS11561 & Algeria & ICARDA & 46 & DS99515 & Kyrgyzstan & ICARDA & 76 & WS12315 & Sweden & $\begin{array}{l}\text { ICARD } \\
\text { A }\end{array}$ \\
\hline 17 & DS11591 & Tunisia & ICARDA & 47 & $\begin{array}{l}\text { EH 06006- } \\
6^{*}\end{array}$ & Ethiopia & HARC & 77 & $\begin{array}{l}\text { WS12424 } \\
2\end{array}$ & China & $\begin{array}{l}\text { ICARD } \\
\text { A }\end{array}$ \\
\hline 18 & DS11689 & Afghanistan & ICARDA & 48 & Gebelcho & Ethiopia & HARC & 78 & WS13039 & Ethiopia & $\begin{array}{l}\text { ICARD } \\
\text { A }\end{array}$ \\
\hline 19 & DS11701 & Afghanistan & ICARDA & 49 & GLA 1103 & Austria & Gleisdorf & 79 & $\begin{array}{l}\text { WS13060 } \\
0\end{array}$ & Russia & $\begin{array}{l}\text { ICARD } \\
\text { A }\end{array}$ \\
\hline 20 & DS11788 & Afghanistan & ICARDA & 50 & ILB938/2* & Ecuador & ICARDA/GU & 80 & $\begin{array}{l}\text { WS13073 } \\
1\end{array}$ & Azerbaijan & $\begin{array}{l}\text { ICARD } \\
\text { A }\end{array}$ \\
\hline 21 & DS11909 & Ethiopia & ICARDA & 51 & Kassa & Ethiopia & HARC & 81 & WS13107 & Greece & $\begin{array}{l}\text { ICARD } \\
\mathrm{A}\end{array}$ \\
\hline 22 & DS12257 & Syria & ICARDA & 52 & Mélodie/2* & France & INRA/GU & 82 & WS13185 & Turkey & $\begin{array}{l}\text { ICARD } \\
\text { A }\end{array}$ \\
\hline 23 & DS124062 & Kazakhstan & ICARDA & 53 & Messay & Ethiopia & HARC & 83 & $\begin{array}{l}\text { WS13223 } \\
8\end{array}$ & China & $\begin{array}{l}\text { ICARD } \\
\text { A }\end{array}$ \\
\hline 24 & DS124138 & China & ICARDA & 54 & NC 58 & Ethiopia & HARC & 84 & $\begin{array}{l}\text { WS13225 } \\
8\end{array}$ & China & $\begin{array}{l}\text { ICARD } \\
\text { A }\end{array}$ \\
\hline 25 & DS124353 & Greece & ICARDA & 55 & Tesfa & Ethiopia & HARC & 85 & $\begin{array}{l}\text { WS13226 } \\
6\end{array}$ & China & $\begin{array}{l}\text { ICARD } \\
\text { A }\end{array}$ \\
\hline 26 & DS13042 & Italy & ICARDA & 56 & WS11309 & Poland & ICARDA & 86 & $\begin{array}{l}\text { WS13227 } \\
4\end{array}$ & China & $\begin{array}{l}\text { ICARD } \\
\text { A }\end{array}$ \\
\hline 27 & DS131708 & Tajikistan & ICARDA & 57 & WS11313 & Ethiopia & ICARDA & 87 & WS99379 & Portugal & $\begin{array}{l}\text { ICARD } \\
\text { A }\end{array}$ \\
\hline 28 & DS13463 & Cyprus & ICARDA & 58 & WS11344 & Russia & ICARDA & 88 & WS99465 & China & $\begin{array}{l}\text { ICARD } \\
\text { A }\end{array}$ \\
\hline 29 & DS13473 & Cyprus & ICARDA & 59 & WS114476 & $\begin{array}{l}\text { Banglades } \\
\mathrm{h}\end{array}$ & ICARDA & 89 & $\begin{array}{l}\text { WS99501 } \\
*\end{array}$ & China & $\begin{array}{l}\text { ICARD } \\
\text { A }\end{array}$ \\
\hline 30 & DS13481 & Cyprus & ICARDA & 60 & WS114576 & $\begin{array}{l}\text { Banglades } \\
\mathrm{h}\end{array}$ & ICARDA & & & & \\
\hline
\end{tabular}

1 


\section{Table 2 (on next page)}

Mean values of shoot and root measurements of 44 faba bean accessions from dry zones and 45 from wet zones. Seed weight data were unreplicated.

$*, * *, * * p<0.05,0.01,0.001$, respectively. SE is standard error and LSD is least significant difference. 


\begin{tabular}{|c|c|c|c|c|c|c|c|c|}
\hline Data & $\begin{array}{c}\text { Stomatal } \\
\text { Conductanc } \\
\text { e }(\mathrm{mmol} \\
\left.\mathrm{H}_{2} \mathrm{O} / \mathrm{m}^{2} / \mathrm{s}\right) \\
\end{array}$ & $\begin{array}{c}\text { Leaf } \\
\text { surface } \\
\text { temperatur } \\
\text { e }\left({ }^{\circ} \mathrm{C}\right) \\
\end{array}$ & $\begin{array}{c}\text { Chlorophyll } \\
\text { concentratio } \\
\text { n (SPAD } \\
\text { value) } \\
\end{array}$ & $\begin{array}{c}\text { Shoot } \\
\text { dry } \\
\text { weigh } \\
\text { t (g) } \\
\end{array}$ & $\begin{array}{c}\text { Root } \\
\text { dry } \\
\text { weigh } \\
\text { t (g) } \\
\end{array}$ & $\begin{array}{c}\text { Root } \\
\text { to } \\
\text { shoot } \\
\text { dry } \\
\text { weigh } \\
\text { t } \\
\text { ratio } \\
\end{array}$ & $\begin{array}{c}\text { Root } \\
\text { mass } \\
\text { fractio } \\
\mathbf{n} \\
\end{array}$ & $\begin{array}{c}\text { Seeds } \\
\text { weigh } \\
\text { t (g) }\end{array}$ \\
\hline Minimum & 109 & 20.7 & 24.1 & 0.27 & 0.21 & 0.31 & 0.24 & 0.12 \\
\hline Mean & 316 & 22.2 & 33.1 & 1.82 & 0.80 & 0.47 & 0.32 & 0.99 \\
\hline Maximum & 752 & 24.8 & 41.0 & 3.49 & 1.59 & 0.94 & 0.50 & 2.11 \\
\hline Mélodie/2 & 252 & 23.3 & 38.7 & 0.74 & 0.38 & 0.51 & 0.32 & 0.5 \\
\hline ILB 938/2 & 383 & 21.7 & 35.8 & 1.92 & 0.84 & 0.44 & 0.30 & 1.04 \\
\hline SE & 65 & 0.7 & 1.6 & 0.27 & 0.12 & 0.13 & 0.04 & \\
\hline LSD (5\%) & 182 & 2.0 & 4.4 & 0.75 & 0.35 & 0.37 & 0.10 & \\
\hline $\begin{array}{l}\text { P-value } \\
\text { (accessions) }\end{array}$ & $* * *$ & $*$ & $* * *$ & $* * *$ & $* * *$ & $* *$ & $* * *$ & \\
\hline Mean dry set & 323 & 22.1 & 34.4 & 2.02 & 0.91 & 0.46 & 0.33 & 1.15 \\
\hline Mean wet set & 308 & 22.2 & 31.7 & 1.63 & 0.71 & 0.47 & 0.32 & 0.68 \\
\hline P-value (sets) & ns & ns & $* * *$ & $* *$ & $* * *$ & ns & ns & \\
\hline
\end{tabular}

1 


\section{Table 3 (on next page)}

Pearson correlations of shoot and root data of 89 faba bean accessions.

$*, * * \mathrm{P}<0.05,0.01$ (2-tailed), respectively. 


\begin{tabular}{|c|c|c|c|c|c|c|c|}
\hline & $\begin{array}{c}\text { Stomatal } \\
\text { conductance }\end{array}$ & $\begin{array}{l}\text { Leaf surface } \\
\text { temperature }\end{array}$ & $\begin{array}{l}\text { Chlorophyll } \\
\text { concentration }\end{array}$ & $\begin{array}{c}\text { Shoot dry } \\
\text { weight }\end{array}$ & $\begin{array}{c}\text { Root dry } \\
\text { weight }\end{array}$ & $\begin{array}{l}\text { Root to } \\
\text { shoot dry } \\
\text { weight } \\
\text { ratio }\end{array}$ & $\begin{array}{l}\text { Root } \\
\text { mass } \\
\text { fraction }\end{array}$ \\
\hline $\begin{array}{l}\text { Canopy } \\
\text { temperature }\end{array}$ & -0.14 & & & & & & \\
\hline $\begin{array}{l}\text { Chlorophyll } \\
\text { concentration }\end{array}$ & $-0.23^{*}$ & -0.04 & & & & & \\
\hline $\begin{array}{l}\text { Shoot dry } \\
\text { weight }\end{array}$ & -0.11 & 0.05 & 0.12 & & & & \\
\hline $\begin{array}{l}\text { Root dry } \\
\text { weight }\end{array}$ & -0.01 & -0.05 & $0.23^{*}$ & $0.89^{* *}$ & & & \\
\hline $\begin{array}{l}\text { Root to shoot } \\
\text { dry weight } \\
\text { ratio }\end{array}$ & 0.08 & -0.05 & 0.08 & $-0.60^{* *}$ & $-0.24^{*}$ & & \\
\hline $\begin{array}{l}\text { Root mass } \\
\text { fraction }\end{array}$ & 0.07 & $\begin{array}{c}-0.03 \\
\end{array}$ & 0.09 & $-0.56^{* *}$ & $-0.21^{*}$ & $0.90^{* *}$ & \\
\hline Seed weight & $-0.78 * *$ & 0.001 & $0.36^{* *}$ & $0.61^{* *}$ & $0.58^{* *}$ & $-0.34 * *$ & $-0.23^{*}$ \\
\hline
\end{tabular}

1 


\section{Table 4(on next page)}

Faba bean accessions chosen for root phenotyping experiment and the bases of selection in the screening experiment. 


\begin{tabular}{|c|c|}
\hline Chosen accessions & Selection criteria \\
\hline DS11202 & $\begin{array}{r}\text { High leaf surface temperature, low chlorophyll concentration, low root } \\
\text { mass fraction and root to shoot dry weight ratio }\end{array}$ \\
\hline DS11320 & Low leaf surface temperature, high root and shoot dry weights \\
\hline DS70622 & Low leaf surface temperature, high root and shoot dry weights \\
\hline DS74573 & High shoot and root dry weight \\
\hline EH 06006-6 & $\begin{array}{r}\text { High leaf surface temperature, low chlorophyll concentration, low root } \\
\text { mass fraction and low root to shoot dry weight ratio }\end{array}$ \\
\hline ILB 938/2 & Benchmark from previous research for drought tolerance \\
\hline Melodie/2 & Benchmark from previous research for efficient use of water \\
\hline WS99501 & $\begin{array}{r}\text { High stomatal conductance, high leaf surface temperature, low root weight, } \\
\text { low root to shoot ratio and low root mass fraction }\end{array}$ \\
\hline
\end{tabular}




\section{Table 5 (on next page)}

Mean root system depth and convex hull area of 8 faba bean accessions at 19 DAT, $n=4$.

*** $p<0.001$, ns (not significant), SE is standard error and LSD is least significant difference.

DAT is days after treatment given. 


\begin{tabular}{|c|c|c|c|c|}
\hline \multirow[b]{2}{*}{ Accessions } & \multicolumn{2}{|c|}{ Root system depth (cm) } & \multicolumn{2}{|c|}{ Convex hull area $\left(\mathrm{cm}^{2}\right)$} \\
\hline & Well watered & Water limited & Well watered & Water limited \\
\hline DS11202 & 74 & 29 & 2061 & 410 \\
\hline DS11320 & 78 & 46 & 2491 & 927 \\
\hline DS70622 & 76 & 53 & 2515 & 1047 \\
\hline DS74573 & 76 & 35 & 2369 & 663 \\
\hline EH 06006-6 & 78 & 34 & 2793 & 679 \\
\hline ILB938/2 & 65 & 31 & 1938 & 397 \\
\hline Melodie/2 & 65 & 32 & 1471 & 476 \\
\hline WS99501 & 61 & 27 & 1592 & 348 \\
\hline SE & \multicolumn{2}{|c|}{3} & \multicolumn{2}{|c|}{162} \\
\hline $\operatorname{LSD}(5 \%)$ & \multicolumn{2}{|c|}{8} & \multicolumn{2}{|c|}{462} \\
\hline Overall & 72 & 36 & 2154 & 618 \\
\hline $\mathrm{SE}$ & \multicolumn{2}{|c|}{1} & \multicolumn{2}{|c|}{81} \\
\hline $\operatorname{LSD}(5 \%)$ & \multicolumn{2}{|c|}{4} & \multicolumn{2}{|c|}{231} \\
\hline \multicolumn{5}{|l|}{ P-value } \\
\hline Treatment & \multicolumn{2}{|c|}{$* * *$} & \multicolumn{2}{|c|}{$* * *$} \\
\hline Accession & \multicolumn{2}{|c|}{$* * *$} & \multicolumn{2}{|c|}{$* * *$} \\
\hline Treatment x Accessi & \multicolumn{2}{|c|}{$\mathrm{ns}$} & \multicolumn{2}{|c|}{$\mathrm{ns}$} \\
\hline
\end{tabular}




\section{Figure 1}

Root and shoot dry weights of 89 faba bean accessions, 45 from wet zones and 44 from dry zones.

Selected accession, from lower left to upper right, are Mélodie/2, WS99501, ILB938/2, EH06006-6, DS11202, DS11320, DS74573 and DS70622. Error bars show least significant difference. Regression line shows root dry weight $=0.353 *$ shoot dry weight $+0.162, r^{2}=$ 0.787 . 


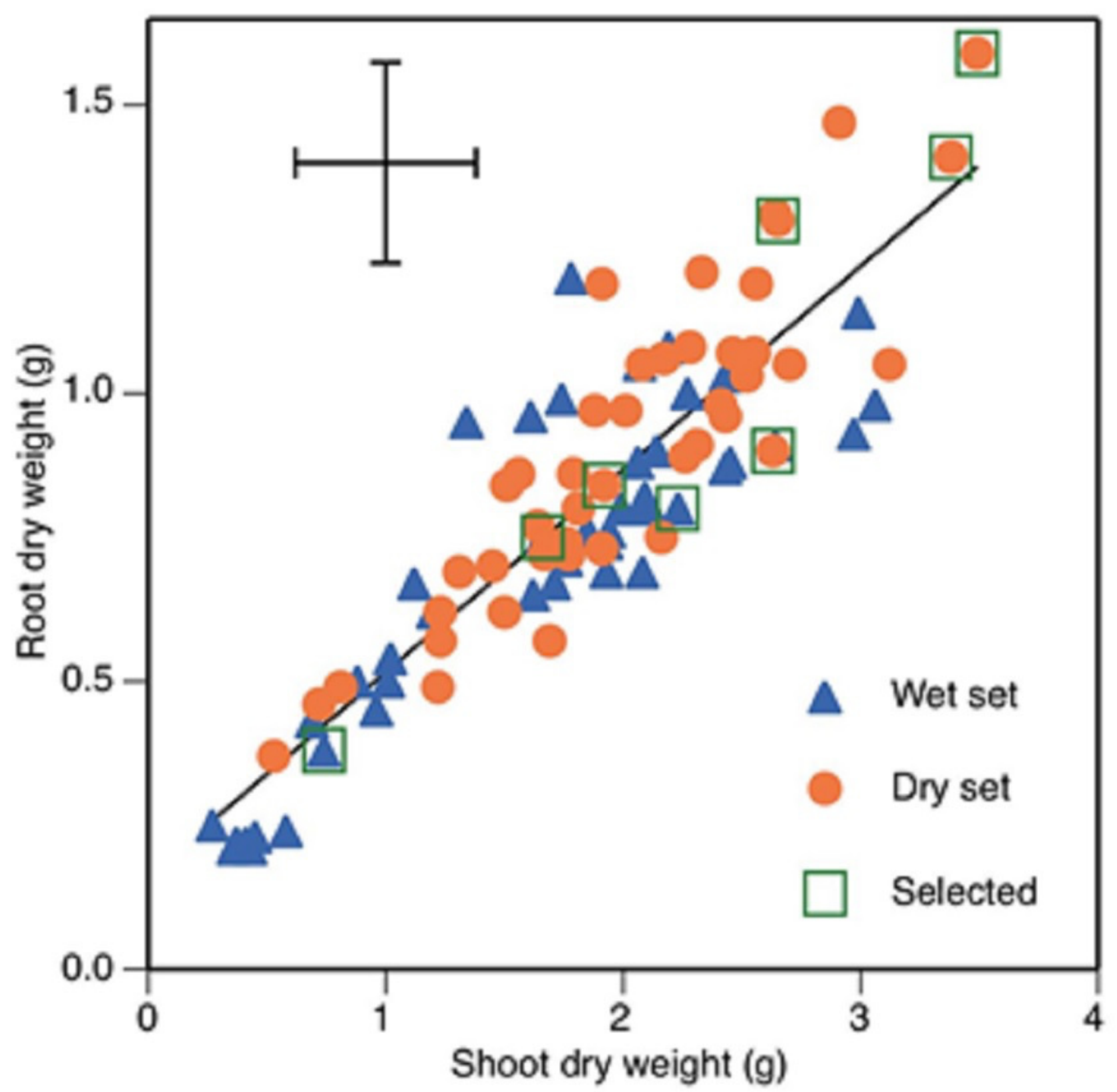


Figure 2

Tap root, lateral and second order lateral root lengths of 8 accessions of faba bean in two water treatments at 19 days after initiation of treatment.

Total root length is the sum of the three classes. Error bars show least significant differences of, bottom to top, taproot, lateral, second order lateral, and total root length.

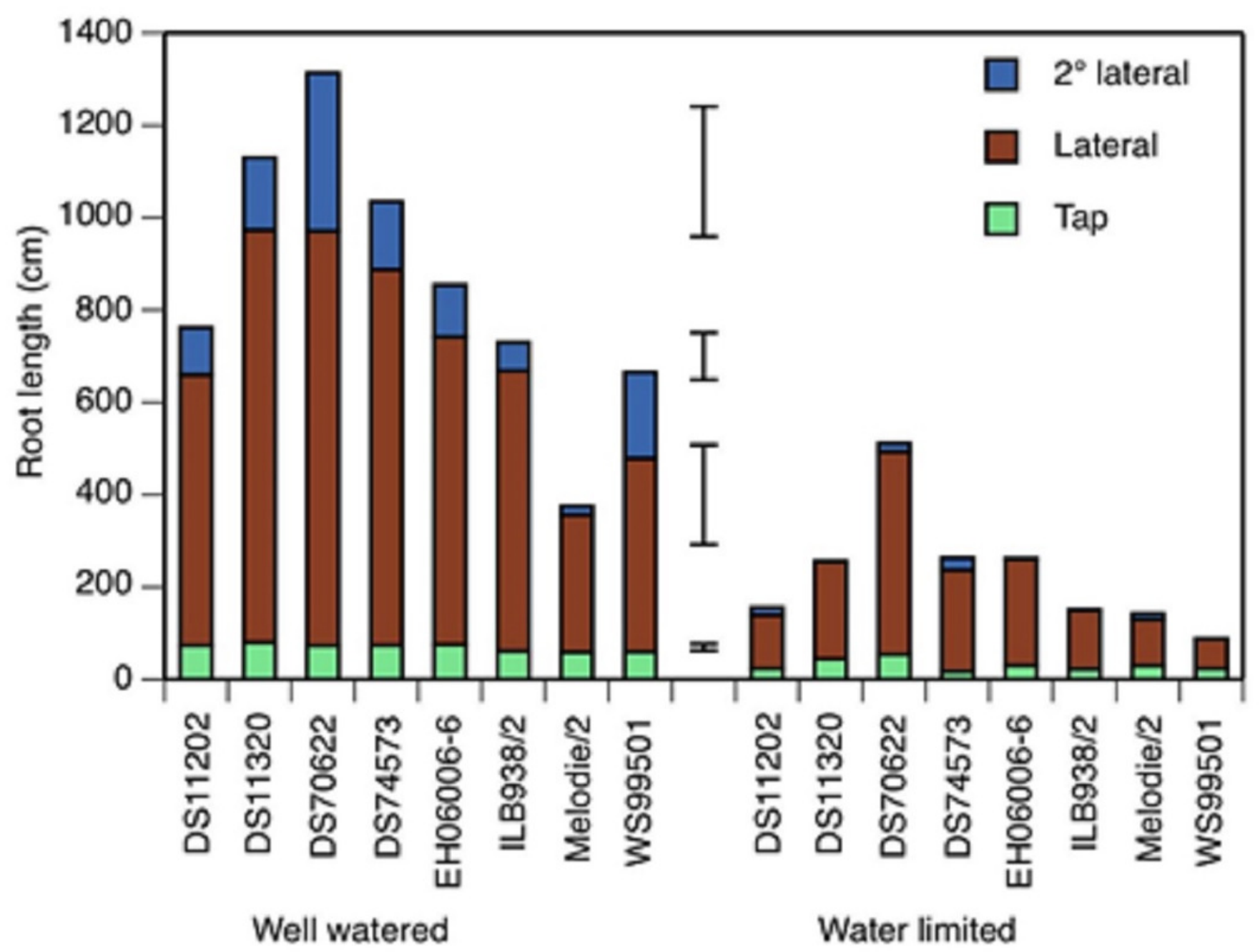




\section{Figure 3}

\section{Examples of GROWSCREEN-Rhizo root images at 19 DAT.}

A, B and C: DS70622, DS74573, Mèlodie/2, respectively, in well watered treatment; D, E, and F in the same order of accessions in water limited treatment. The outlined area in image $\mathrm{E}$ shows the convex hull area. Each image shows the full $70 \mathrm{~cm}$ width of the RhizoBox.

*Note: Auto Gamma Correction was used for the image. This only affects the reviewing manuscript. See original source image if needed for review.

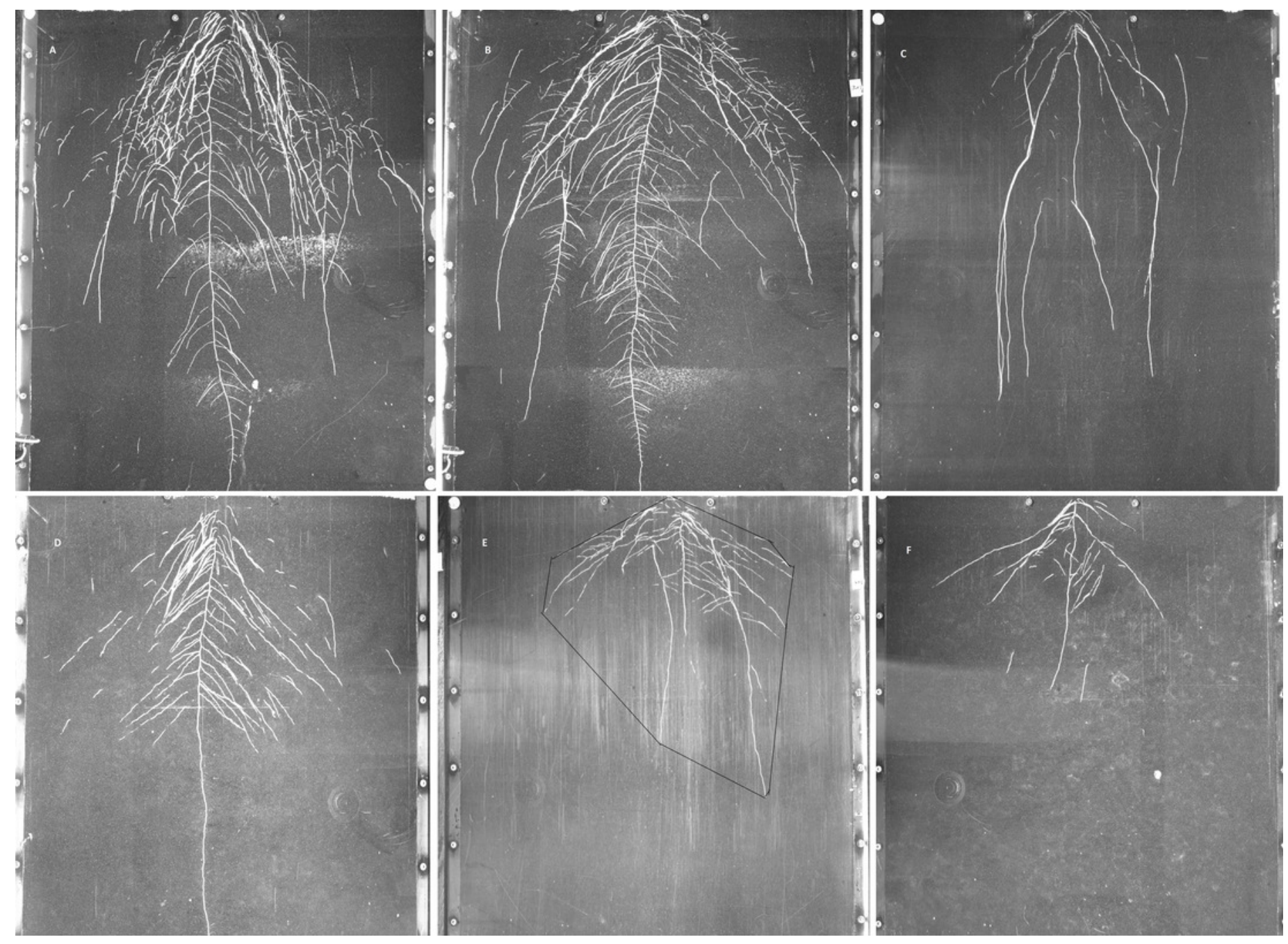

